\title{
Colorful ESL Test Papers And Spatial Intelligence: Should One Simply Throw Paint on Exam Papers to Ameliorate them in the Eyes of Spatially Intelligent Candidates?
}

\author{
Dennis Moradkhan (Corresponding author) \\ Islamic Azad University North Tehran Branch, Iran \\ E-mail: d_moradkhan@iau-tnb.ac.ir \\ Kourosh Karimi \\ Islamic Azad University North Tehran Branch, Iran \\ E-mail: Cyrusk1971@yahoo.com \\ Atoosa Aryan \\ Islamic Azad University UAE Branch, Dubai, UAE \\ E-mail: atia_20@yahoo.com
}

Received: 10-06-2014

Accepted: 26-07-2014

Published: 01-11-2014

doi:10.7575/aiac.ijalel.v.3n.6p.176

URL: http://dx.doi.org/10.7575/aiac.ijalel.v.3n.6p.176

\begin{abstract}
The purpose of this research was to find out whether introducing color as an element which may appeal to spatiallyintelligent candidates affects their performance on ESL grammar tests. 52 participants were given two parallel grammar tests, one in black and white and the other bearing the full spectrum of colors in the natural daylight. In order to identify the candidates with visual-spatial learning style, the participants and their teachers were asked to respond to VisualSpatial Identifier rating scale. Based on the results, no significant relationship was found between the performance of candidates on the colorful and black and white grammar tests and their visual-spatial intelligence. It was concluded that other variables including the method of applying colors, the type and combination of colors as well as the differential impact of different colors on candidates with different cultural backgrounds needed to be addressed before any conclusions can be drawn about the application of color in language assessment.
\end{abstract}

Keywords: assessment, colorful exam papers, multiple intelligences, spatial intelligence

\section{Introduction}

In the past two decades, researchers involved in the field of language testing and assessment have focused their attention on three assessment trends. On the one hand, there were calls to involve learners in actually performing the behavior that they would do in naturalistic settings (Bachman, 2002). On the other, dynamic assessment has paid increasing attention to individual differences among test-takers (Lantolf \& Poehner, 2004, 2011; Sternberg \& Grigorenko, 2002). Similarly, test designers were urged to adopt a more ethical stance with respect to language tests by critically addressing the test bias which is considered a serious issue in traditional tests (Shohamy, 2001). It seems that, the theory of multiple intelligences (MI) shares a common interface with these relatively recent developments in the field of language assessment. Particularly, those who wish to draw pedagogical implications from MI subscribe to similar agenda.

The founder of the MI theory, Howard Gardner, believed that tests should simulate the settings that candidates are expected to function in real-life contexts. According to Gardner, "when individuals are assessed in situations that more closely resemble actual working conditions, it is possible to make much better predictions about their ultimate performance" (1993, p. 181). Gardner also believed that most testing instruments mainly favored the traditionally valuable intelligences, namely the linguistic and logical-mathematical intelligence. The reasonable alternative, he believed, is "to devise instruments that are intelligence fair, that peer directly at the intelligence in operation rather than proceeding via the detour of linguistic and logical faculties" (Gardner, 1993, p. 182). Similarly, one of the pioneers of applying MI in second language education, Mary Christison, maintained that language assessment should seek to accommodate the diversity of learning styles and abilities (2005). Indeed, there is a common thread running through the theory of MI and modern approaches to language assessment.

Since its conception in the early 1980s, the MI theory has attracted many educators and policymakers both in the general education and language teaching. Many educational establishments have set about designing their curricula around the notion of MI and quite a few enthusiastic teachers have attempted MI-based creative teaching and assessment strategies to address the special needs of different learners with a diverse set of aptitudes, native languages and cultures (e.g., Anderson, 1998; Armstrong, 2009; Gardner, 1991, 2006; Haley, 2001; Palmberg, 2011; William \& 
Anders, 2005). In fact, Gardner considered the contribution of MI to education as self-evident; since learners are endowed with distinct faculties and mental predispositions, realized in different combinations of intelligences, teachers would do well to teach and assess them using different techniques through appropriate teaching and assessment methods and tools. Unless teachers recognize the particular intellectual strengths of their learners, and translate this into different teaching methods and assessment instruments, we cannot expect to tackle some of the most fundamental issues in the classrooms (Armstrong, 2009).

According to the MI theory, people are thought to have several intelligences one of which is visual-spatial intelligence which is defined as the ability to apprehend and process the visual world and to mentally recreate and manipulate different facets of the visual experience even in the absence of physical stimuli (Gardner, 1993). Gardner (1985) proposed that spatial intelligence "emerges as an amalgam of abilities which is loosely tied to and developed out of the individual's observation of visual world" (p. 183). People with high levels of spatial intelligence are thought to be more responsive to form, space, color and, shape (Christison, 1998).

Visual-spatial intelligence has attracted much attention in the educational circles. This is because there is much evidence for scientific achievement (Uttal \& Cohen, 2012), creative productivity (Mann, 2005), and mathematical higher-order thinking (Lohman, 1996) in individuals with spatial strengths. Gardner (1985) proposed that this intelligence can be used to fulfill "a variety of scientific ends, as a useful tool, and aid to thinking, a way of capturing information, a way of formulation of problems, or the very means of solving problems" (p. 192). Spatial intelligence is also believed to play an important role in linguistic processing.

Thomas Armstrong (2003) stated:

The person who reads and writes is doing far more than linguistically encoding data. She is also looking at the visual configuration of the letters. Thus, spatial intelligence, the intelligence of pictures and images, must first be brought to bear on the printed letters. (p. 19)

\subsection{Statement of the Problem and Significance of the Study}

Despite the crucial role of the visual-spatial intelligence in educational settings, most of the educational materials and many of the tests which are used to identify gifted learners or to assess achievement in students consistently fail to address this particular intelligence (Gallagher \& Johnson, 1992). Instead, most university admissions tests and other high stakes testing emphasize the mathematical and verbal abilities (Mann, 2005). A disturbing consequence of this is the possibility that some intellectually promising students are put at a disadvantage as a result of the disregard to their spatial ability.

One of the proposed ways to ameliorate this situation is to manipulate the graphic representation of the test papers by introducing color as an element which may appeal to spatially-intelligent candidates. Armstrong criticized the monotony of applying dull black and white colors in the learning context and proposed that spatially intelligent students are presented with visually captivating and dynamic verbal materials such as colorful handouts and tests with interesting fonts and colors (2003, p.54).

Since color is considered as a remarkable element in the educational contexts (Daggett, Cobble \& Gertel, 2008; Mann, 2001; Silverman, 2002; Simmons, 1995), and because spatially intelligent learners are believed to be more responsive to color (Christison, 1998), this research seeks to examine the relationship between ESL learners' level of spatial intelligence on the one hand and their performance on colorful versus black and white $(\mathrm{B} / \mathrm{W})$ test papers on the other. To be more precise, the main goal of this study is to verify whether introducing color in grammar tests is in any way related to the candidates' performance, particularly as regards the spatially intelligent learners for whom the visual mode is the preferred means of sensory perception.

\subsection{Research Questions}

This study aimed to answer the following questions:

1. Do the grammar scores of ESL candidates differ on a black and white $(B / W)$ and colorful tests?

2. Is there any relationship between ESL learners' level of spatial intelligence and their performance on black and white $(\mathrm{B} / \mathrm{W})$ versus colorful test papers?

Accordingly, the following null hypotheses were raised:

$\mathrm{H}_{0} 1$ : There isn't a significant difference between the scores of the candidates on $B / W$ and colorful tests.

$\mathrm{H}_{0}$ 2: There isn't a significant correlation between ESL learners' level of spatial intelligence and their scores on $\mathrm{B} / \mathrm{W}$ versus colorful test papers.

\section{Method}

\subsection{Participants}

This study was performed in Al-Ain Iranian Private School in UAE. The participants were 52 pre-intermediate ESL students of the school, of which 27 were male and 25 were female. The selection process was based on intact group convenience sampling. In terms of their language proficiency, the sample of participants was considered as homogeneous on the basis of their narrow range of scores obtained from the school's placement test and the fact that they were all assigned to the 'intermediate' level of the school. The students were between the ages of ten and thirteen. 


\subsection{Instrumentation}

Two instruments were used in the data collection: Visual-Spatial Identifier and a grammar achievement test based on the course book of the students, 'English Time' (Rivers \& Toyama, 2003).

\subsubsection{Grammar test}

Two parallel achievement grammar tests were used in the study. These tests were prepared by the researchers in two different layouts, one in color and the other in black and white $(\mathrm{B} / \mathrm{W})$. However, the tests were otherwise identical both in terms of format (margin, font size and border width) and content. A table of specification was used to ascertain that both tests covered the same content that reflected students' course book. Both tests had the same number of items with similar difficulty indices covering 'parts of speech', 'verb forms' and 'word order'. (See Appendixes A and B for the two parallel forms of the grammar test).

In the B/W test the borders and spacers bore many shades of gray as well as black, but in the colorful test, the borders and spacers were given the full spectrum of the colors found in the natural daylight, with a complete coverage of wavelengths from red to violate. This decision was made in order to counterbalance the potential impact of any individual color on the candidates. The rationale for using color in borders and spacers rather than the text itself was based on much research that found performance on language tasks was affected by the color in the background of the actual task (e.g., Murnane, Phelps \& Malmberg, 1999; Rahmah, Hafiza \& Tengku Nazatul Shima, 2012).

Both grammar tests were first piloted with a similar group of candidates from another school in order to standardize them. In this process the faulty items were removed and the remaining 47 items were used in the study. The reliability of the grammar tests in the actual administration was found to be quite high, i.e., 0.82 and 0.83 for the B/W and colorful tests respectively.

\subsubsection{Visual-Spatial Identifier}

The candidates' level of spatial intelligence was assessed through a questionnaire called Visual-Spatial Identifier (VSI) obtained and used with explicit written permission of the copyright holders (See Appendix C for the permission letter of the copyright holder). Developed and validated by Silverman, VSI is an instrument which is used to distinguish learners with a predisposition to the visual-spatial learning style from those who show a natural preference for auditorysequential learning style. It was validated with a 750-strong sample of White and Hispanic children between the ages of 9 and13 in different geographical areas and was shown to be reasonably reliable (r=.7046). (Silverman, 2002)

VSI comes in two versions: an observer form completed by a parent or teacher and a self-rating form for students (See Appendixes D and E for the two versions of VSI). Both questionnaires contain fifteen questions with five randomly distributed statements for each preference based on a 5-point Likert Scale with responses ranging from 1 "not true" to 5 "very true". Both versions of the questionnaire were translated into Persian by the researchers (See Appendixes F and G for a translated copy of the two versions of VSI).

\section{Procedure}

First, in order to assess the spatial intelligence of student participants a translated version of VSI was given to their teachers at Al-Ain Iranian School. The teachers were asked to carefully study the questionnaire and observe their students' learning styles for one month before they complete the survey. Then, the self-rating version of VSI was administered to 52 pre-intermediate ESL learners. In order to make sure that the students would understand and respond to the survey accurately, the researcher explained every item of the questionnaire to the participants and waited for them to answer the questions one by one. Next, the participants were asked to mention to what extent they went along with each item on a scale from 1 to 5 . The results collected from both forms of the visual-spatial survey were used to rank the participants into two groups, namely 'high' and 'low' VSI groups.

In order to compare the student's results on B/W and colorful tests, they were given two parallel achievement grammar tests developed in two different layouts, one in color and the other in black and white format. After that, descriptive statistics for grammar tests was generated in SPSS and their KR 21 reliability was worked out.

Based on the students' results in the colorful and B/W tests, the participants were divided into 3 groups. The first group $(n=19)$ comprised of the candidates who did better in the colorful test. The second group $(n=21)$ were the students who fared better in the B/W test. And the third group $(n=12)$ were the ones whose scores were the same in both tests or varied only within 0.75 points. In order to control for the likely influence of the order of administration of colorful or $\mathrm{B} / \mathrm{W}$ tests, half of the students first were given the colorful test papers and the remaining participants received B/W papers. Finally, to answer the research questions and address the research hypotheses, a wide range of statistical analyses were performed using the SPSS and Excel.

\section{Design}

The research design of the study was a descriptive ex post facto correlational design, without any manipulation of variables. The two variables which were examined were the presence of color in grammar tests and the spatial intelligence.

\section{Results}

The descriptive statistics for the scores of the students on colorful and B/W grammar tests are shown in table 1 and table 2 respectively. 
Table 1. Descriptive Statistics of Students' Scores on B/W Test

\begin{tabular}{llllllll}
\hline & $\mathrm{N}$ & Minimum & Maximum & Mean & Std. Deviation & Skewness \\
\cline { 2 - 8 } & Statistic Statistic & Statistic & Statistic & Statistic & Statistic & Std. Error \\
Test in B/W & 52 & 14 & 40 & 29.15 & 7.454 & -.618 & .330 \\
Valid N (list wise) & 52 & & & & & & \\
\hline
\end{tabular}

Table 2. Descriptive Statistics of Students' Scores on Colorful Test

\begin{tabular}{llllllll}
\hline & $\mathrm{N}$ & Minimum & Maximum & Mean & Std. Deviation & Skewness \\
\cline { 2 - 7 } & Statistic & Statistic & Statistic & Statistic & Statistic & Statistic & Std. Error \\
Test in Colorful & 52 & 7 & 40 & 29.46 & 7.678 & -1.007 & .330 \\
Valid N (list wise) & 52 & & & & & & \\
\hline
\end{tabular}

The results in table 1 show that the distribution of the students' score on the B/W test is almost normal, while the results in table 2 indicate that the students' scores in the colorful test are not normally distributed. Since the students' scores on the second set were not normally distributed, non-parametric tests such as Wilcoxon Signed Ranks test and MannWhitney were consulted for comparing their results.

Wilcoxon Signed Ranks test was used to compare the participants' scores on the B/W and colorful tests. Tables 3 and 4 show the results.

Table 3. Ranks of Students on the Two Tests

\begin{tabular}{lllll}
\hline & & N & Mean Rank & Sum of Ranks \\
\cline { 2 - 4 } Test in Color - Test in B/W & Negative Ranks & $23^{\mathrm{a}}$ & 23.48 & 540.00 \\
& Positive Ranks & $25^{\mathrm{b}}$ & 25.44 & 636.00 \\
& Ties & $4^{\mathrm{c}}$ & & \\
Total & 52 & & \\
\hline
\end{tabular}

a. Test in Color $<$ Test in Black \& White

b. Test in Color $>$ Test in Black \& White

c. Test in Color $=$ Test in Black \& White

Table 4. Test Statistics ${ }^{\text {a }}$ Comparing Students' Performance on Two Tests

\begin{tabular}{ll}
\hline & Test in Color - Test in B/W \\
\hline$Z$ & $-.493^{\mathrm{b}}$ \\
Asymp. Sig. (2-tailed) & .622 \\
\hline
\end{tabular}

a. Wilcoxon Signed Ranks Test

b. Based on negative ranks

As table 3 shows, 25 students performed better on the colorful test, 23 did better on the B/W test and 4 candidates received exactly the same scores on the two tests. According to Table 4 , the difference would be significant at 0.622 which is higher than our significance level of 0.05 . As a result, we can conclude that the performance of students on the two sets of scores is not significantly different. Therefore, the first null hypothesis which states 'there isn't a significant difference between the scores of the candidates on B/W and colorful tests' could not be rejected.

In order to verify whether the students who enjoyed higher levels of spatial intelligence fared better on the colorful test, all the participants were divided into two groups of high and low VSI according to their teachers' ranking. At this stage Mann-Whitney Test was consulted because the scores were not normally distributed. Table 5 shows the descriptive statistics for the high and low VSI scores according to the teachers' report.

Table 5. Descriptive Statistics of High/Low Groups Ranked by Teacher for B/W Test

\begin{tabular}{lllll}
\hline & $\begin{array}{l}\text { Teacher's } \\
\text { ranking }\end{array}$ & $\mathrm{N}$ & Mean Rank & Sum of Ranks \\
\cline { 2 - 4 } Test in B/W & High & 26 & 27.21 & 707.50 \\
& Low & 26 & 25.79 & 670.50 \\
& Total & 52 & & \\
\hline
\end{tabular}


Table 6 shows test statistics for the difference between high and low groups on black and white test.

Table 6. Test Statistics ${ }^{\mathrm{a}}$ for Difference between High/Low Groups on B/W Test

\begin{tabular}{ll}
\hline & Test in B/W \\
\hline Mann-Whitney U & 319.500 \\
\hline Wilcoxon W & 670.500 \\
\hline$Z$ & -.339 \\
\hline Asymp. Sig. (2-tailed) & .735 \\
\hline
\end{tabular}

a. Grouping Variable: Teacher's ranking

As we can see in table 6, the difference between the two groups would be significant at 0.735 which is much higher than 0.05 . Therefore, we can conclude that based on teacher ranking, there was no significant difference between the scores of students with high and low spatial intelligence on the $\mathrm{B} / \mathrm{W}$ test.

Again, Mann-Whitney Test was consulted to verify if the scores of the participants with high or low spatial intelligence (based on teachers' ranking) were significantly different. Tables 7 and 8 show the results.

Table 7. Descriptive Statistics of High/Low Groups Ranked by Teacher for Colorful Test

\begin{tabular}{lllll}
\hline & $\begin{array}{l}\text { Teacher's } \\
\text { ranking }\end{array}$ & $\mathrm{N}$ & Mean Rank & Sum of Ranks \\
\cline { 2 - 5 } Test in Color & High & 26 & 27.13 & 705.50 \\
& Low & 26 & 25.87 & 672.50 \\
& Total & 52 & & \\
\hline
\end{tabular}

Table 8. Test Statistics ${ }^{\mathrm{a}}$ of Difference between High/Low Groups on Colorful Test

\begin{tabular}{ll}
\hline & Test in Color \\
\hline Mann-Whitney U & 321.500 \\
\hline Wilcoxon W & 672.500 \\
\hline$Z$ & -.302 \\
\hline Asymp. Sig. (2-tailed) & .763 \\
\hline
\end{tabular}

a. Grouping Variable: Teacher's ranking

Table 8 shows that the difference between the two groups would be significant at 0.763 which is much higher than 0.05 . Thus, it can be concluded that again there was no significant difference between the scores of participants with high and low visual-spatial intelligence on the colorful test. Based on the results in tables 6 and 8, no relationship could be found between the students' level of spatial intelligence and their performance on the B/W versus colorful test papers. Therefore, the second null hypothesis which states 'there isn't a significant correlation between ESL learners' level of spatial intelligence and their scores on B/W versus colorful test papers' could not be rejected either.

In order to accommodate the students' own attitudes with regard to their spatial intelligence, the same procedure was repeated, but this time it was based on their self-report both for the colorful and B/W tests. Tables 9 to 12 present the results.

Table 9. Descriptive Statistics of High/Low Groups Self-Ranked by Students for B/W Test

\begin{tabular}{lllll}
\hline & $\begin{array}{l}\text { Students' } \\
\text { ranking }\end{array}$ & $\mathrm{N}$ & Mean Rank & Sum of Ranks \\
\cline { 2 - 5 } Test in B/W & High & 26 & 23.60 & 613.50 \\
& Low & 26 & 29.40 & 764.50 \\
Total & 52 & & \\
\hline
\end{tabular}

Interestingly, as is evident in Table 9, the mean of the students' scores on B/W test in the 'high' VSI group is lower than the 'low' VSI group. 
Table 10. Test Statistics ${ }^{\mathrm{a}}$ for Difference between High/Low Groups on B/W Test

\begin{tabular}{ll}
\hline & Test in B/W \\
\hline Mann-Whitney U & 262.500 \\
\hline Wilcoxon W & 613.500 \\
\hline$Z$ & -1.382 \\
\hline Asymp. Sig. (2-tailed) & .167 \\
\hline
\end{tabular}

a. Grouping Variable: Students' ranking

The same analyses were performed for the colorful test, the results of which are recorded in tables 11 and 12 .

Table 11. Descriptive Statistics of Color Test for High/Low Groups Self-ranked by Students

\begin{tabular}{lllll}
\hline \multirow{4}{*}{ Test in Color } & $\begin{array}{l}\text { Students' } \\
\text { ranking }\end{array}$ & N & Mean Rank & Sum of Ranks \\
\cline { 2 - 5 } & High & 26 & 23.69 & 616.00 \\
& Low & 26 & 29.31 & 762.00 \\
\hline & Total & 52 & & \\
\hline
\end{tabular}

Again, as evidenced by the results in Table 11, it is curious to note that, the mean in the 'low' VSI group for B/W grammar test is higher.

Table 12. Test Statistics ${ }^{\mathrm{a}}$ for Difference between High/Low Groups on Colorful Test

\begin{tabular}{ll}
\hline & Test in Color \\
\hline Mann-Whitney U & 265.000 \\
\hline Wilcoxon W & 616.000 \\
\hline$Z$ & -1.336 \\
\hline Asymp. Sig. (2-tailed) & .181 \\
\hline
\end{tabular}

a. Grouping Variable: Students' ranking

Based on the results in tables 10 and 12 we can conclude that there was not any significant difference between the 'high' and 'low' VSI groups on the colorful grammar test based on students' self-report.

\section{Discussion}

As we saw in the results section, no significant difference was found between the scores of the students on B/W test papers compared to colorful test papers. Nor a significant relationship was detected between the scores of students on the $\mathrm{B} / \mathrm{W}$ and colorful grammar tests on the one hand, and their spatial intelligence as obtained from both versions of VSI questionnaires on the other.

These results seem to contradict the strands of research that support the purposeful application of color in educational settings (e.g. Daggett et al., 2008; Mann, 2001; Silverman, 2002). The results of current study were also at odds with those scholars who advocate the use of captivating colors on test papers (Armstrong, 2003). The equivocal results of this study, however, need to be interpreted with respect to other relevant literature and evaluated with due attention to the limitations imposed on the study so that we can explore its potential implications for the field of language assessment.

As mentioned in 2.2, the element of color was used only in borders and spacers of the grammar test rather than the text itself. However, one can argue that the way colors were applied in this study might have failed to engage the perceptual apparatus of the participants in a serious way. This is justifiable because in the colorful tests the element of color was not integrated into the fabric of the test papers in a meaningful way, but just suspended in the background where the candidates could well miss the wide array of colors thrown at them. That is to say, the participants did not need to tap into their visual intelligence in order to tackle the questions in the grammar tests. This barely meets the criteria set by Gardner for testing tools that "peer directly at the intelligence in operation rather than proceeding via the detour of linguistic and logical faculties" (Gardner, 1993, p. 182).

Furthermore, the use of color on exam papers, whether in the background or within the text, has proved to be a contentious issue. On the one hand, some studies (e.g., Daggett et al., 2008) maintain that color can enhance student achievement and concentration through visual and mental stimulation. Other researches (e.g., Sinclair, Soldat \& Mark, 1998) found that "students whose examination forms are on colors that convey more positive affect may process 
information less systematically, leading to differential performance on the examination" (p. 130). Still, others found differential impacts of different colors on candidates in testing environments. Elliot et al. (2007), for instance, found that candidates who were exposed to red on their exam papers associated the color with failure causing debilitating levels of anxiety leading to poorer performance compared with those who were exposed to other colors. Therefore, this issue warrants careful deliberation, taking into account other variables such as the age, gender, linguistic and cultural background of candidates as well as the nature of the subject being assessed using a variety of different instruments.

Another topic of value for further research would be to investigate the degree of correlation between the teacher-report versus self-report on the participants' spatial intelligence. The present study did not make an attempt to account for the discrepancy between the two, nor did it venture into reconciling them by training the teachers and students and raising their awareness to look for the specific behavioral qualities of interest. It is proposed to use a range of awareness-raising techniques to make both students and teachers more insightful about the concept. This is because an awareness of learning styles allows learners to maximize their potential, and affords the teachers an opportunity to provide their students with approaches that suit their style preferences best (Griffiths, 2012).

\section{Conclusion}

Brown (2010) suggests that the theory of multiple intelligences has had an indirect impact on the field of language assessment. This is because MI addresses probably one of the most important issues in SLA: i.e. individual differences in second language learning (Dornyei \& Skehan, 2003, Griffiths, 2012). The significance of visual-spatial intelligence in academic achievement is also a well-researched topic (Uttal \& Cohen, 2012). But when it comes to the specific implications of the theory in terms of using color on ESL exam papers, as evidenced by this paper, the results are mixed and the literature is divided. In fact, this is a topic marred with complexities. For example, the method of applying colors and the type and combination of colors applied (Elliot et al., 2007), the effects of color on memory encoding and retrieval (Martinez, Crystal, Oberle \& Thopson Jr, 2010), and particularly the differential impact on learners with different styles and cultures (Ou et al., 2012) are all outstanding issues that need to be addressed properly before educators can draw definitive conclusions about its implications for language assessment in Iranian context.

This, however, by no means should condone the sheer disregard for the diverse learning styles of the learners on the pretext of practical and budgetary considerations. Nor should it excuse an exclusive focus on the traditionally valuable intelligences and a failure to accommodate learners with other intelligences or those who cannot comfortably relate to the format of most standard instruments. Instead, the researchers wish to draw the attention of practitioners and administrators to the urgency of addressing the special needs of visually intelligent learners in Iranian schools and institutes by providing them with the enriching physical stimuli that they need.

\section{Acknowledgements}

The authors wish to thank Professor Steven Hass, the director of visual-spatial identifier project at the Institute for the Study of Advanced Development based in Westminster, Colorado in USA for granting us the permission to use VSI identifier and providing us with the necessary guidelines to score the questionnaires.

\section{References}

Anderson, V. B. (1998). Using Multiple Intelligences to improve retention in foreign language vocabulary study. Education Resources Information Center. Retrieved from http://files.eric.ed.gov/fulltext/ED424745.pdf

Armstrong, T. (2009). Multiple intelligences in the classroom (3rd ed.). Alexandria, VA: Association of Supervision and Curriculum Development.

Armstrong, T. (2003). The Multiple Intelligences of reading and writing. USA, Virginia, Alexandria: Association for supervision and curriculum development.

Bachman, L. (2002). Some reflections on task-based language performance assessment. Language Testing, 19, 453-476. Brown, H.D. (2010). Language assessment: Principles and classroom practices (2nd ed.). NY: Pearson Longman.

Christison, M. A. (1998). Applying Multiple Intelligences Theory in pre-service and in-service TEFL education programs. [Electronic version]. Forum, 36(2), 2-13.

Christison, M. A. (2005). Assessment as a starting point in second language teacher education. Proceedings from the EFL Testing and Evaluation Forum, American Hellenic Center, October 16, 2004, Athens, Greece.

Daggett, W., Cobble, J., \& Gertel, S. (2008). Color in an optimum learning environment. International Center for Leadership in Education, Rexford, NY. Retrieved from http://www.successfulpractices.org/spn/media/files/articles/research/Color\%20white\%20paper.pdf

Dornyei, Z., \& Skehan, P. (2003). Individual differences in second language learning. In C. Doughty \& M. Long (Eds.), Handbook of second language acquisition (pp. 589-630). Oxford: Blackwell.

Elliot, A. J., Maier, M. A., Moller, A. C., Friedman, R., \& Meinhardt, J. (2007). Color and psychological functioning: The effect of red on performance attainment. Journal of Experimental Psychology: General, 136, 154-168. 
Gallagher, S.A., \& Johnson, E.S. (1992). The effect of time limits on performance of mental rotations by gifted adolescents. Gifted Child Quarterly, 36, 19-22.

Gardner, H. (1985). The mind's new science: A history of the cognitive revolution. New York: Basic Books.

Gardner, H. (1991). The unschooled mind: How children think, and how schools should teach.New York: Basic Books.

Gardner, H. (1993). Frames of the mind: The theory of multiple intelligences 10th Anniversary Edition. New York: Basic Books.

Gardner, H. (2006). Multiple intelligences: New horizons. New York: Basic Books.

Griffiths, C. (2012). Learning styles: Traversing the quagmire. In S. Mercer, S. Ryan \& M. Williams (Eds.), Psychology for language learning: insights from research, theory and practice (pp. 151-168). Basingstoke, England: Palgrave Macmillan.

Haley, M. H. (2001). Understanding learner-centered instruction from the perspective of multiple intelligences. Foreign Language Annals, 34(4), 355-67.

Lantolf, J. P., \& Poehner, M. E. (2004). Dynamic assessment in the language classroom (CALPER Professional Development Document CPDD-0411). University Park, PA: The Pennsylvania State University, Center for Advanced Language Proficiency Education and Research.

Lantolf, J. P., \& Poehner, M. E. (2011). Dynamic assessment in the classroom: Vygotskian praxis for second language development. Language Teaching Research, 15(1), 11-33.

Lohman, D. F. (1996). Spatial ability and g. In I. Dennis, \& P. Tapsfield (Eds.), Human abilities: Their nature and measurement (pp. 97-116). Hillsdale, NJ: Erlbaum.

Mann, R.L. (2001). Eye to eye: Connecting with gifted visual spatial learners. Gifted Child Today 25 (4), 54-57. Mann, R. L. (2005). Gifted students with spatial strengths and sequential weaknesses: An overlooked and under-identified population. Roeper Review, 27, 91-96.

Martinez, J. V., Oberle, C. D., \& Thompson, J. G. Jr. (2010). Effects of color on memory encoding and retrieval in the classroom. American Journal of PsychologicalResearch, 6(1), 24-31.

Murnane, K., Phelps, M. P., \& Malmberg, K. (1999). Context-dependent recognition memory: The ICE theory. Journal of Experimental Psychology: General, 128(4), 403-415.

Ou, L. C., Luo, M. R., Sun, P. L., Hu, N. C., Chen, H. S., Guan, S. S., Woodcock, A., Caivano J, L., Huertas, R., Tremeau, A., Billger, M., Izadan, H., Richter, K. (2012). A cross-cultural comparison of colour emotion for two-colour combinations. Color Research and Application, 37(1), 23-43.

Palmberg, R. (2011). Multiple Intelligences Revisited. Palmsoft Publications. Retrieved from http://www.englishclub.com/esl-lesson-plans/EC-multiple-intelligences-revisited.pdf

Rahmah, L., Hafiza, A., and Tengku Nazatul Shima, T. P. (2012). Affective Engineering of Background Colour in Digital Storytelling for Remedial Students. ELSEVIER Procedia-Social and Behavioral Sciences (Vol. 68, 19, pp 202212). Elsevier.

Rivers, S., Toyama, S. (2003). English Time, New York, NY10016, USA.

Shohamy, E. (2001). The power of tests: A critical perspective on the uses of language tests. London: Longman.

Silverman, L. K. (2002). Upside-down brilliance: The visual-spatial learner. Denver, CO: DeLeon Publishing.

Sinclair, R. C., Soldat, A. S., \& Mark, M. M. (1998). Affective cues and processing strategy: Color-coded examination forms influence performance. Teaching of Psychololgy, 25(2), 130-132.

Simmons, S. (1995, December). Drawing as thinking. Think Magazine, 23-29.

Sternberg, R. J., \& Grigorenko, E. L. (2002). Dynamic testing. New York: Cambridge University Press.

Uttal, D. H., \& Cohen, C.A. (2012). Spatial thinking and STEM education: When, why, and how. In B. Ross (Ed.), Psychology of learning and motivation (Vol. 57, pp 147-181). Academic Press Elsevier.

William, W., \& Anders, L. (2005). Differentiating instruction in the teaching Spanish as a Foreign Language course using multiple intelligence theory. International Journal of Learning. 2005/2006, Vol. 12 Issue 6, p9-14.

\section{Notes}

Note 1. The colorful version of the grammar test is included in Appendix B, but based on publisher's policies and for practical considerations it is presented in black and white. 
Subject: English Time:45 minutes

A.Circle verbs in each sentence below.

1. Ali listens to his favorite song.

2. Fardin hits the baseball over the fence.

3. The little pig grunts.

4. The roof of the house leaks.

5. The hunter searches for a rabbit.

6. Dr. Feizi examines his patient.

B.Tell whether each word is a verb or noun. Write the word verb next to each verb. Write the word noun next to each noun.
1. swims
2. thinks
3. sleep
4. clock
5. tooth
6. drives

\section{Complete the sentences.}

Example: I didn 't watch TV last night. 
1. My brother (travel) to Iran last summer.

2. I (walk) to school because there weren't any buses.

D. Write the past simple of these verbs.

1. awake

2. be

3. beat

4. listen

5. become

6. play

7. like

8. move

9. blow

10.build---:--

\section{E. Write the questions in the correct order.}

Example:

night? / meet / Did / you / them / last /

Did you meet them last night?

1. film? / like / you / Did / the /

2. you / many / did / ask? / How / people / 
3. a / have / time? / they / Did / good /

\section{F. Regular (R) or irregular (I) verbs?}

Example: play $\mathbf{R}$
1. sit
2. feel
3. thank
4.drink
5. win
6.jump.
7.swim
8. give
9. read
10.clean.

\section{G. Complete with past simple (regular or regular} verbs).

1. We all (go) into school.

2. Our cat (run) onto the road.

3. Jane (not write) a letter.

4. I (buy) a new camera last week.

5. Yesterday Dad (not take) me to the carnival. 
6. Elizabeth (give) Eva a chocolate.

7. I (put) sugar in my coffee.

8. $\mathrm{He}$ (not hit) the ball over the net.

9. Yesterday I (get) up early, at about seven o'clock.

10. After lunch I (sleep) for a few hours.

\section{Good Luck}


Appendix B

Colorful grammar test

\section{Subject: English Time:45 minutes}

A. Circle the action verb in each sentence below.

1. The bluebird in the tree sings beautifully.

2. The football team dashes out of the locker room.

3. Paul reads The Adventures of Tom Sawyer.

4. Mrs. Fatemeh buys a book at the store.

5. Yasaman solves the mystery.

6. Safa finds a purple crayon.

B. Tell whether each word is a verb or noun. Write the words verb next to each verb. Write the word noun next to each noun.

1. takes

3. plays

5. grass

\section{C . Complete the sentences.}

Example: I didn 't watch TV last night.
2. basketball

4. bring

6. game 
1. On Saturday I (play) computer games with my cousins.

2. My mum (not cook) dinner last night.

\section{Write the past simple of these verbs.}

1. bring---------

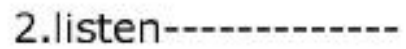

3.say

4.take

5.teach------------

6.sleep---1----

7.tell

8.learn

9.give-------------10.sing----

\section{E. Write the questions in the correct order}

Example: night? / meet / Did / you / them / last / Did you meet them last night?

1. did / weekend? / the / What / do / we / at /

2. she / DVD? / Where / that / did / buy / 
3. party / on / your / go / Saturday? / he / Did / to /

\section{F. Regular (R) or irregular (I) verbs?}

Example: play $\mathbf{R}$

1. fly

3. study

5. make

7. see

9.tell
2. use

4. eat

6. travel

8.try

10. be

\section{G. Complete with past simple (regular or regular} verbs).

1. I opened the door and (look) inside.

2. Who (close) all the windows?

3. I (not climb) over the fence.

4. I (wash) my shirt.

5. Dinosaurs (live) many years ago. 
6. They (not work) until twelve last night.

7. I kicked the ball and it (break) a window.

8. I (get) this book from the library.

9. The glass (not break).

10. We (buy) a new car.

\section{GOOD LUCK}


Appendix C

Copyright holder's permission letter to use VSI

\section{Good Horing. Aloosd!}

Thark you for your inqLiry requesting perrission to use the Visual-Spatial Identifiere for your dissertation. Your research topic sounds interesting and cculd contribute to our knowledge of the role of color in assessments "or visual-spatial learners. We would be happy to have you use the VSIO in that research. We ask only that 1; you give attribution to the Institute for the Study of Advanced Development. as the copyright owmer and developer of the VSIF, and 2j that you kindly send us an electronic copy of your finished wcrk so that wo can add it to our rescarch files on the vSl: and its oxpanding international use.

Wishing you best of luck with your research,

\section{Steven C. Haas, Director}

Visual-Spatial Identifier Project

Institute for the Study of Advanced Development

(303) 837-8378 (work)

(303) 596-4200 (cell)

From: GDC Customer Service

<customerservice@gifteddevelopment.com>

Subject: Re: Message From Visual-Spatial Resource

Date: June 17, 2013 9:35:43 AM MDT

To: Linda Silverman <giftedness101@gmail.com>, Steven Haas <sandihaas@mac.com> 
Appendix D

Spatial intelligence questionnaire (self-report)

\section{Gifted Development Center}

a service of The Institute for the Study of Advanced Development

8120 Sheridan Blvd., Suite C-111 0 Westminster, $\mathrm{CO}$

$80003-6104 \circ(303) 837-8378$

THIS IS A PRINTABLE COPY

\section{The Visual-Spatial Identifier}

(Self Report)

Name

Age

Gender

Please indicate the degree to which the following descriptors apply:

$1=$ not true 2 = somewhat true $3=$ mostly true $4=$ true $5=$ yery true

1. I hate speaking in front of a group.

$\begin{array}{lllll}1 & 2 & 3 & 4 & 5\end{array}$

2. I think mainly in pictures instead of words.

$\begin{array}{lllll}1 & 2 & 3 & 4 & 5\end{array}$

3. I am good at spelling.

$\begin{array}{lllll}1 & 2 & 3 & 4 & 5\end{array}$

4. I often lose track of time

$\begin{array}{lllll}1 & 2 & 3 & 4 & 5\end{array}$

5. I know more than others think I knowy.

$\begin{array}{lllll}1 & 2 & 3 & 4 & 5\end{array}$

6. I don't do well on tests with time limits.

$123 \quad 4 \quad 5$

7. I have neat handwriting.

$123 \quad 3 \quad 4 \quad 5$

8. I have a wild imagination.

$\begin{array}{lllll}1 & 2 & 3 & 4 & 5\end{array}$

9. I like to take things apart to find out how they work.

$\begin{array}{lllll}1 & 2 & 3 & 4 & 5\end{array}$

10. I hate writing assignments.

$\begin{array}{lllll}1 & 2 & 3 & 4 & 5\end{array}$

11. I solve problems in unusual ways.

$123 \quad 3 \quad 4 \quad 5$

12. It's much easier for me to tell you about things than to write about $1 \begin{array}{lllll}1 & 2 & 3 & 4\end{array}$ them.

13. I have a hard time explaining how I come up with my answers.

$\begin{array}{lllll}1 & 2 & 3 & 4 & 5\end{array}$

14. I am well organized.

$\begin{array}{lllll}1 & 2 & 3 & 4 & 5\end{array}$

15. It was easy for me to memorize my math facts.

$\begin{array}{lllll}1 & 2 & 3 & 4 & 5\end{array}$

Please feel free to make any comments that you feel will improve this questionnaire: 
Appendix E

Spatial intelligence questionnaire (observer- report)

\section{The Visual-Spatial Identifier}

(Observer Report)

Subject's

Name

Age

Gender

Your Name

Relationship to Subject

If a teacher is filling out this form, it would be best if the teacher sees the student at least three times a wreek. Please indicate the degree to which the following descriptors apply: $1=$ not true

$2=$ somewhat true $3=$ mostly true $4=$ true $5=$ very true

1. Dislikes public speaking

2. Thinks in images instead of words

3. Is a good speller

4. Does not budget time well

5. Resists demenstrating what she or he knows

6. Has trouble with timed tests

7. Has neat handwriting

8. Is extraordinarily imaginative

9. Takes things apart to find out how they work

10. Is frustrated with writing assignments

11. Solves problems in unusual ways

12. Oral expression is much better than written expression

13. Reaches correcl conclusions without apparent steps

14. Is well organized

15. Memorized math facts easily

$\begin{array}{lllll}1 & 2 & 3 & 4 & 5 \\ 1 & 2 & 3 & 4 & 5 \\ 1 & 2 & 3 & 4 & 5 \\ 1 & 2 & 3 & 4 & 5 \\ 1 & 2 & 3 & 4 & 5 \\ 1 & 2 & 3 & 4 & 5 \\ 1 & 2 & 3 & 4 & 5 \\ 1 & 2 & 3 & 4 & 5 \\ 1 & 2 & 3 & 4 & 5 \\ 1 & 2 & 3 & 4 & 5 \\ 1 & 2 & 3 & 4 & 5 \\ 1 & 2 & 3 & 4 & 5 \\ 1 & 2 & 3 & 4 & 5 \\ 1 & 2 & 3 & 4 & 5 \\ 1 & 2 & 3 & 4 & 5\end{array}$

Please feel free to make any comments that you feel will improve this questionnaire: 
Appendix F

Translated version of spatial intelligence questionnaire (self- report) in Persian

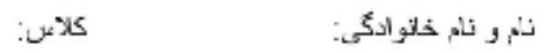

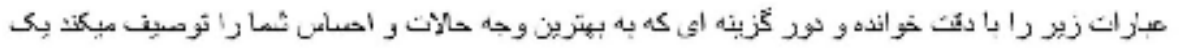

$$
\text { نايره بكثيث. }
$$

$$
\begin{aligned}
& \text { |- دوست ندازم جلوى مردم صحبت كندر }
\end{aligned}
$$

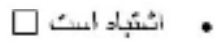

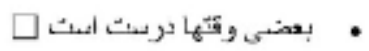

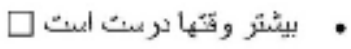

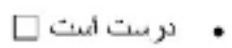

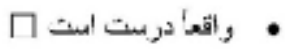

ז-براى فكر كردن بيشتر از تصاوير استفاده مى كنمر تا از كلمات

$$
\begin{aligned}
& \text { • انشبَّاد السك }
\end{aligned}
$$

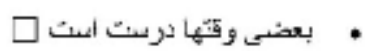

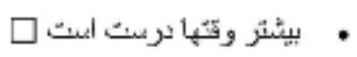

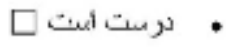

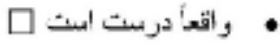

$$
\begin{aligned}
& \text { ז- در اسبل كردن كلمان مهارت دارم }
\end{aligned}
$$

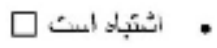

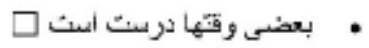




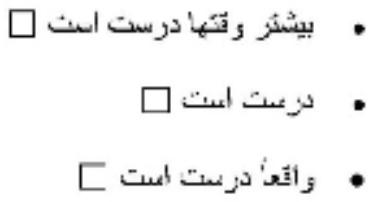

ץ- معمولا وقت از دليسته در مى رود

$$
\text { • }
$$

ه- من از اونى كه مردم فكر مى كتند بيشتر مى دانم

$$
\begin{aligned}
& \text { 口 اشتباد أحت • }
\end{aligned}
$$

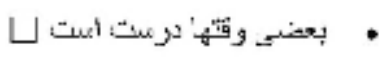

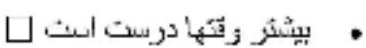

$$
\begin{aligned}
& \text { • مزيت ائت } \\
& \text { • • • }
\end{aligned}
$$

\&- من با امتعاناتى كه وقت معدود دارند مشكل دارم

$$
\begin{aligned}
& \text { 口 اشتبنه أست . }
\end{aligned}
$$

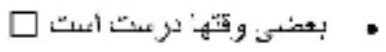

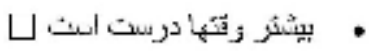

$$
\begin{aligned}
& \text { • ل عبث است }
\end{aligned}
$$




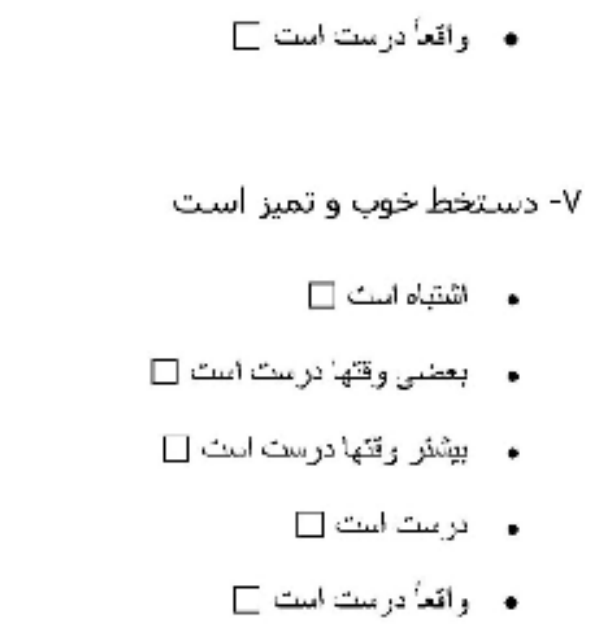

^ - من تخيلات ريادى ذر ذهنه مييرورانمر

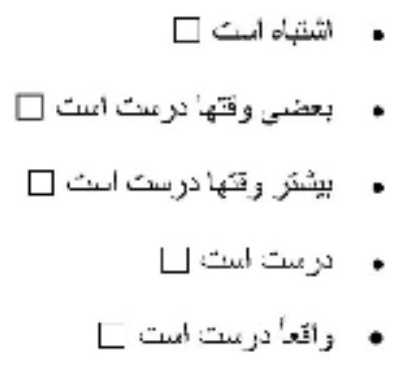

9 - دوست دارمر دستُّاه ها رو بار كنمر تا ببينم קتطور كار مى كنند

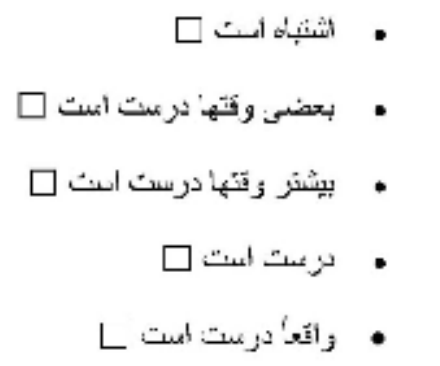




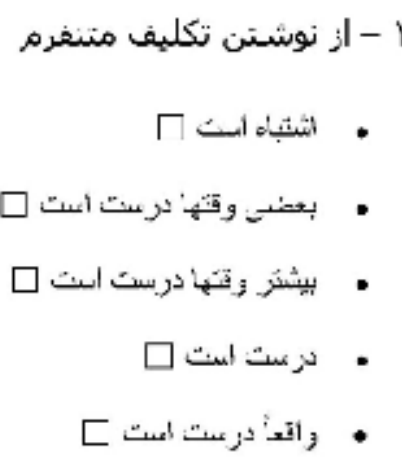

| ا- مساتل رو با روشى منفاوت از ديكّران حل مى كنم

$$
\begin{aligned}
& \text { 口 اشتباه أست . }
\end{aligned}
$$

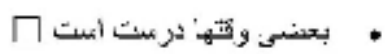

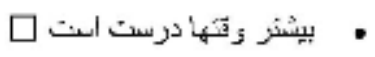

$$
\begin{aligned}
& \text { • مزعت امتت } \\
& \text { ᄃ • • }
\end{aligned}
$$

Tا- راحت تز هسته, كه يك موضوع را يكمة تا اينكه بنويسم.

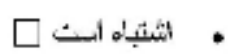

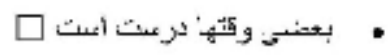

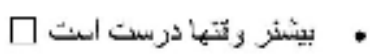

$$
\begin{aligned}
& \text { • ل لزيت إست } \\
& \text { • • }
\end{aligned}
$$

با - براى من توضيح دادن جوايهايى كه به سوالها مى دهم, سخت است

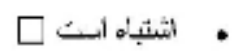




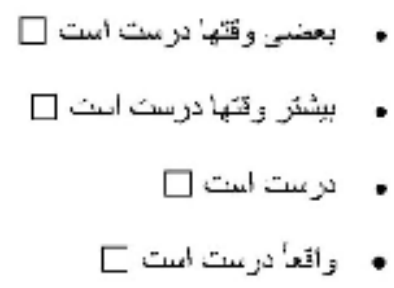

| ا - خيلى منظمر هستمر

口 الشتباه أست .

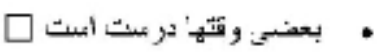

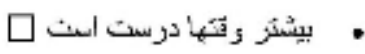

$\square$ • •

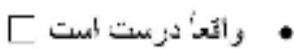

10 - حغظ كردن مفانهبم رباضى برايمر آسان است

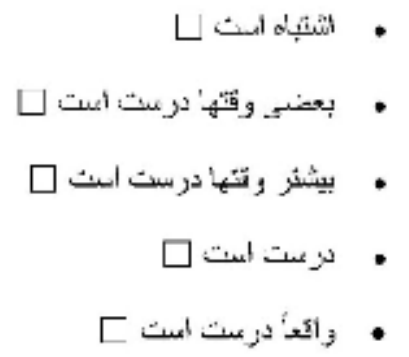

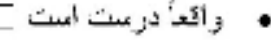


Appendix G

Translated version of spatial intelligence questionnaire (observer- report) in Persian

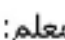

كxin

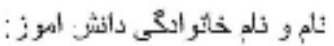

ا-صحبت كردن در جمع را دوست نذارد

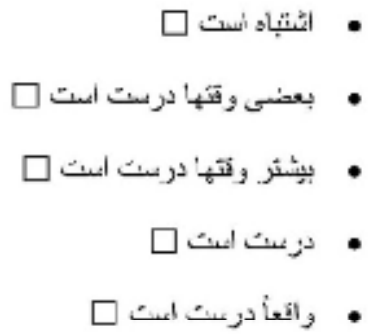

ז- براى فكر كردن بيشـتر از تصاوير الستفاده مى كتد تا از كلمات

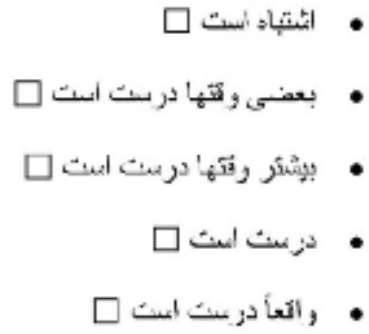

T- در هجى كردن كلمات مهارت دارد

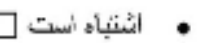

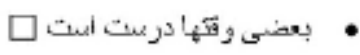

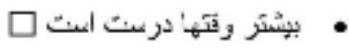

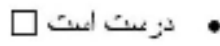

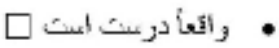


ب- در مديريت زمان موفقيت جندانى نذارد

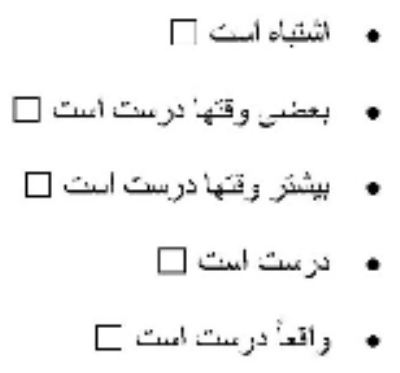

ه- از ابراز كردن دانسته هايش خوددارى مى كند

$$
\begin{aligned}
& \text { • ا شتبنه أست }
\end{aligned}
$$

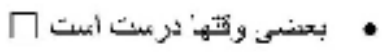

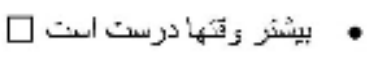

$$
\begin{aligned}
& \text { • ل نزمت استت } \\
& \text { ᄃ • • }
\end{aligned}
$$

و- با امتحانهاى داراى محدوديت زمانى مشكل دارد

$$
\begin{aligned}
& \text { • • الشبّان الست }
\end{aligned}
$$

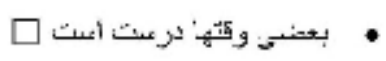

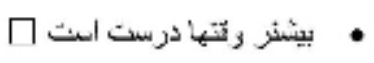

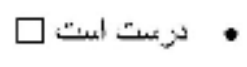

$$
\begin{aligned}
& \text { • • }
\end{aligned}
$$

V- دست خطش خيلى خوب و تميز است

$$
\text { 口 اشثبده أست . }
$$




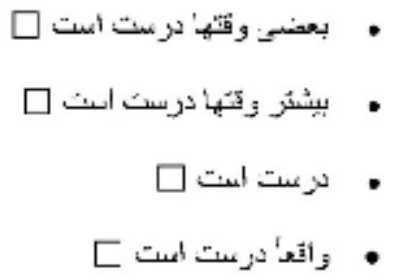

A- قدرت تخيل فوق الماده دارد

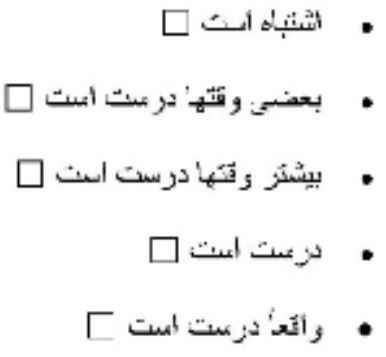

9 دوست دارد وسايل را باز كند تا ببيند حطور كار مى كنند.

$$
\begin{aligned}
& \text { L }
\end{aligned}
$$

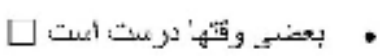

$$
\begin{aligned}
& \text { • بيثئر رتشئ درست است } \\
& \text { • }
\end{aligned}
$$

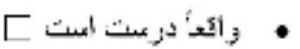

$$
\begin{aligned}
& \text { + ا- از تكليفماي نوشتنى بدش مى أيد } \\
& \text { • أشتباه است . } \\
& \text { • بعضت وقته' دربت: أعت: ل }
\end{aligned}
$$

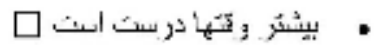




$$
\text { • • ل }
$$

| - مسائل را به روشـهاى غير معمولى حل مى كند

$$
\text { ᄃ أشتباد أست }
$$

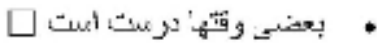

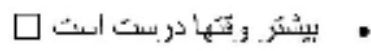

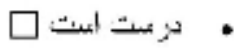

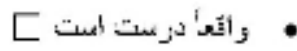

זו - در بيان شغاهى بهتر از نوشتن است

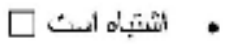

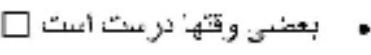

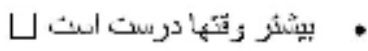

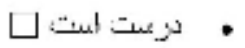

$$
\begin{aligned}
& \text { • • }
\end{aligned}
$$

TI - بذون طى مراحل مشخص به تتيجه كيرى درست مى زسـ

$$
\begin{aligned}
& \text { 口 أشتبه است • }
\end{aligned}
$$

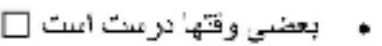

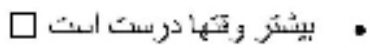

$$
\begin{aligned}
& \text { • • لزعت الست ل } \\
& \text { ᄃ • }
\end{aligned}
$$




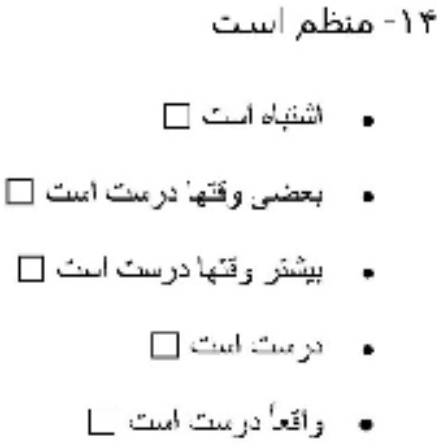

10 - مفاهيم رياضى را براحتى خفظ مى كند

$$
\begin{aligned}
& \text { • أشتبنه أست . }
\end{aligned}
$$

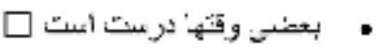

$$
\begin{aligned}
& \text { • بيثنز و يتجبا درست است } \\
& \square \text { • }
\end{aligned}
$$

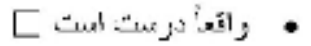

